\title{
IN VITRO ANTIDIABETIC AND IN VIVO ANTIDIARRHEAL ACTIVITY OF ONCOBA SPINOSA ROOTS
}

\author{
Prasanth Kumar $M^{1 *}$, Suba V. ${ }^{2}$, Ramireddy $B^{3}$, Srinivas Babu $P_{.}^{4}$
}

\begin{abstract}
1.Faculty of Pharmaceutical Sciences, JNTU, Hyderabad, Telangana.

2.Dept. of Pharmacology, National Institute of Siddha, Tambaram Sanatorium, Chennai.

3.Director-Formulations, NATCO Pharma, Hyderabad, Telangana.

4.Principal, Vignan Pharmacy College, Vadlamudi, Guntur, Andhrapradesh.
\end{abstract}

Submitted: 01-03-2015

Revised: 25-04-2015

Accepted: 15-05-2015

*Corresponding author Prasanth Kumar M

Email:

prasanth.pharmacology @gmail.com

\section{INTRODUCTION}

Diabetes mellitus is a group of heterogenous disorders characterised by chronic hyperglycaemia mainly due to absolute (type 1 insulin-dependent) or relative (type 2 noninsulin-dependent) deficiency of insulin hormone. By 2030, the worldwide estimation of diabetic patients is likely to be more than double from that of 2005 without any intervention (Gershell 2005). Every year, about $5 \%$ of the deaths worldwide are likely related to diabetes (Hiremath et al., 2010). Diarrheal diseases are one of the leading causes of morbidity and mortality in developing countries and are responsible for the death of millions of people every year (Carlos et al., 1990). Despite immense technological advancement in modern medicine, many people in the developing countries still rely on the healing practices and medicinal plants for their daily health care needs (Ojewole 2008). Therefore, the World Health Organization encouraged studies for the treatment and prevention of diarrheal diseases and diabetes treatment depending on traditional medical practices (Atta et al., 2004).

Oncoba spinosa, the snuff-box tree, fried egg tree or fried-egg flower, is a spiny shrub that belongs to Flacourtiaceae which has 95 genera and 800-1000 species. The leaves are dark, glossy green in colour and somewhat leathery and hairless. The fruits are grown up to $60 \mathrm{~mm}$ in diameter, it consists of hard shell that becomes dark-reddish brown when mature with shiny seeds embedded in a dry yellowish pulp (Burkil 1984). Fruits and leaves are used for colds, fever, female infertility; seed oil as febrifuge. Traditionally the plant is used in the treatment of diabetes and tumour. The roots of Oncoba spinosa are used in the treatment of dysentery and bladder complaints (Burkil 1994). To the best of our knowledge, no reports were available on the antidiarrheal activity and antidiabetic activity of Oncoba spinosa roots. The aim of the present work was to study and evaluate the biological activity of roots of Oncoba spinosa as an $\alpha$-glucosidase inhibitor, an $\alpha$-amylase inhibitor, and an antidiarrheal. 


\section{MATERIALS AND METHOD}

\section{Collection and identification of the plant materials}

Fresh roots of Oncoba spinosa were collected from Tirupathi, Andhrapradhesh. The plant was identified and authenticated taxonomically by Assistant professor $\mathrm{K}$. Madhava chetty of the Department of Botany, S.V.University, Tirupathi, Andhra Pradesh, India. A voucher specimen of the collected sample was deposited in the herbarium of the institution for future reference.

\section{Preparation of the extract}

The roots are shade dried, made into coarse powder and extraction was done by using cold maceration process for $72 \mathrm{~h}$ successively by using petroleum ether, chloroform, ethylacetate and ethanol and filtered to get extracts of respective solvents. All the extracts were vaccum dried to obtain chloroform extract (CEOS), ethylacetate extract (EAOS) and ethanol extract (EEOS) respectively. The ethanolic extract was suspended in 1\% CMC and used for in-vivo antidiarrheal evaluation.

\section{Experimental animals}

Albino wistar rats (weighing between 150-200g) of both sexes were selected for the antidiarrheal studies. They had free access to food and water and were maintained under standard laboratory conditions which included $12 \mathrm{~h}$ light-dark cycle and temperature of 28-30 degrees centigrade. Animals are allowed for a one week of acclimatization period prior to the study. The experimental protocol was approved by the IAEC (institutional animal ethical committee) and care of the experimental animals was taken according to the CPCSEA guidelines.

\section{In-vitro a-amylase inhibition assay}

One hundred micro liter of the test extract was allowed to react with $200 \mu \mathrm{L}$ of $\alpha$-amylase enzyme and $100 \mu \mathrm{L}$ of $2 \mathrm{mM}$ of phosphate buffer (pH-6.9). After 20min incubation, $100 \mu \mathrm{L}$ of $1 \%$ starch solution was added. The same was performed for the controls where $100 \mu \mathrm{L}$ of the test extract was replaced by buffer. After incubation for $5 \mathrm{~min}$, $500 \mu \mathrm{L}$ of dinitrosalicylic acid reagent was added to both control and test. They were kept in boiling water bath for $5 \mathrm{~min}$. The absorbance was recorded at $540 \mathrm{~nm}$ using spectrophotometer and the percentage inhibition of $\alpha$ amylase enzyme was calculated using the below formula. Acarbose was used as positive control. Inhibition $(\%)=100\left(\frac{\text { Control }- \text { Test }}{\text { Control }}\right)$

Suitable reagent blank and inhibitor controls were simultaneously carried out.

Concentrations of extracts resulting in $50 \%$ inhibition of enzyme activity ( IC $_{50}$ ) were determined graphically (Bernfeld, 1955).

\section{In-vitro a-glucosidase assay}

A volume of $60 \mu \mathrm{L}$ of sample solution and $50 \mu \mathrm{L}$ of $0.1 \mathrm{M}$ phosphate buffer $(\mathrm{pH}$ 6.8) containing $\alpha$-glucosidase solution $(0.2 \mathrm{U} / \mathrm{mL})$ was incubated at $37^{\circ} \mathrm{C}$ for $20 \mathrm{~min}$. After preincubation, $50 \mu \mathrm{L}$ of $5 \mathrm{mM}$ p-nitrophenyl- $\alpha$-Dglucopyranoside (PNPG) solution in $0.1 \mathrm{M}$ phosphate buffer ( $\mathrm{pH}$ 6.8) was added and incubated at $37^{\circ} \mathrm{C}$ for another $20 \mathrm{~min}$. Then the reaction was stopped by adding $160 \mu \mathrm{L}$ of $0.2 \mathrm{M} \mathrm{Na} \mathrm{CO}_{3}$, and absorbance readings were recorded at $405 \mathrm{~nm}$ and compared to a control which had $60 \mu \mathrm{L}$ of buffer solution in place of the extract. For blank incubation (to allow for absorbance produced by the extract), enzyme solution was replaced by buffer solution and absorbance recorded. The $\alpha$ glucosidase inhibitory activity was expressed as inhibition \%. Acarbose was used as positive control (Kaskoos 2013).

Inhibition $(\%)=100\left(\frac{\text { Control }- \text { Test }}{\text { Control }}\right)$

Concentrations of extracts resulting in 50\% inhibition of enzyme activity (IC ${ }_{50}$ ) were determined graphically.

\section{Castor oil ind uced diarrhea}

Rats selected for the experiment are fasted for $18 \mathrm{~h}$ with only access to water are divided into five groups of six animals each. Group I received vehicle 1\% CMC, group II received $100 \mathrm{mg} / \mathrm{kg}$ of EEOS orally, group III received $200 \mathrm{mg} / \mathrm{kg}$ of EEOS orally, group IV received $400 \mathrm{mg} / \mathrm{kg}$ of EEOS orally and group $\mathrm{V}$ received atropine $3 \mathrm{mg} / \mathrm{kg}$ i.p. After $1 \mathrm{~h}$ of treatment with the extract, standard drug and vehicle, $1 \mathrm{~mL}$ of castor oil was given orally to all 
the five groups of animals. The rats were then placed in metabolic cages and the floor of the cages was lined with adsorbent papers in order to collect the faeces. All the animals are to be observed for four hours for the presence of diarrhea (Shoba et al., 2001; Ujjin et al., 2005).

Antidiarrheal activity of the drug or extract was expressed in terms of percent inhibition of diarrhea. The percent inhibition of defecation was calculated by using the formula:

$\%$ Inhibition of defecation $=\left[\frac{(\mathrm{X}-\mathrm{Y})}{\mathrm{X}}\right] \times 100$

$\mathrm{X}$ is the mean number of defecation caused by castor oil and $\mathrm{Y}$ is the mean number of defecation caused by drug or extract.

\section{Castor oil induced enteropooling}

Rats selected for the experiment are fasted for 18 hours with only access to water are divided into five groups of six animals each. Group I received vehicle 1\% CMC, group II received $100 \mathrm{mg} / \mathrm{kg}$ of EEOS orally, group III received $200 \mathrm{mg} / \mathrm{kg}$ of EEOS orally, group IV received $400 \mathrm{mg} / \mathrm{kg}$ of EEOS orally and group $\mathrm{V}$ received atropine $3 \mathrm{mg} / \mathrm{kg}$ i.p. After 1 hour of treatment with the extract, standard drug and vehicle, $1 \mathrm{~mL}$ of castor oil was given orally to all the five groups of animals. After $1 \mathrm{~h}$ of treatment with castor oil, rats from all the groups were sacrificed and whole intestine from the pylorus to caecum was removed after tying the ends with thread and weighed. The contents of the intestine were collected by milking into a graduated tube. The intestine was reweighed and the difference between the full and empty intestine was measured in grams (Robert et al., 1976).

$\begin{aligned} & \text { Percentage of } \\ & \text { intestinal fluid inhibition }=\end{aligned}=\frac{\left(T_{c}-T_{t}\right)}{T_{c}} \times 100$

$T_{c}$ : Mean fluid accumulation in control group and $T_{t}$ :Mean fluid accumulation in test group

\section{Charcoal meal test or gastrointestinal motility test}

Rats selected for the experiment are fasted for $18 \mathrm{~h}$ with only access to water are divided into five groups of six animals each. Group I received vehicle 1\% CMC, group II received $100 \mathrm{mg} / \mathrm{kg}$ of EEOS orally, group III received $200 \mathrm{mg} / \mathrm{kg}$ of EEOS orally, group IV received $400 \mathrm{mg} / \mathrm{kg}$ of EEOS orally and group
$\mathrm{V}$ received atropine $3 \mathrm{mg} / \mathrm{kg}$ i.p. After $1 \mathrm{~h}$ of treatment with the extract, standard drug and vehicle, $1 \mathrm{~mL}$ of castor oil was given orally to all the five groups of animals. After $1 \mathrm{~h}$ of treatment with castor oil, $1 \mathrm{~mL}$ of marker $(10 \%$ charcoal suspension in 5\% gum acacia) was administered orally to all the animals in all the five groups. The rats were sacrificed after one hour and the small intestine was removed surgically and the distance travelled by the charcoal meal from pylorus to caecum was measured after keeping the intestine on a clean transparent clean glass and the values are expressed as percentage with respect to the total length of the intestine from pylorus to caecum (Mascolo et al., 1994). The percentage of inhibition was also calculated by using the following formula (Mujumdar 1998).

$\begin{aligned} & \text { Distance } \\ & \text { travelled }(\%)=\end{aligned}$
$\begin{aligned} & \text { Inhibition } \\ & (\%)=\end{aligned} \quad \begin{gathered}\text { Total length } \\ \text { Total length-Distance } \\ \text { travelled by the charcoal }\end{gathered}$
$\frac{\text { Total length }}{\text { Total }}$

\section{Statistical analysis}

Results are expressed as mean \pm SEM. Data obtained was analyzed by using one way ANOVA followed by Dunnett's test and $\mathrm{p}<0.05$ was considered as statistically significant.

\section{RESULTS AND DISCUSSION Preliminary phytochemical analysis}

Results obtained for qualitative screening of phytochemicals in roots of Oncoba spinosaare presented in table I.

\section{In-vitro a-amylase inhibition assay}

The $\alpha$-amylase inhibitory effect of CEOS was found to be ranging from $3.61 \pm 0.42 \%$ to $26.80 \pm 0.58 \%$. The $\alpha$-amylase inhibitory effect of EAOS was found to be ranging from $5.91+0.56 \%$ to $61.18+0.17 \%$ when studied at concentrations $62.5-1000 \mu \mathrm{g} / \mathrm{mL}$. At same concentration, the inhibitory effect of EEOS was found to be ranging from $8.64+0.66 \%$ to $79.94+0.65 \%$ whereas the effect of the standard drug acarbose, ranged from $18.54+0.31 \%$ to $82.73+0.65 \%$. 
Table I. Qualitative phytochemical analysis of O. spinosa roots

\begin{tabular}{clccc}
\hline S.No & Chemical Constituent & CEOS & EAOS & EEOS \\
\hline 1 & Alkaloids & - & - & - \\
2 & Carbohydrates & - & + & + \\
3 & Glycosides & - & + & + \\
4 & Anthroquinones & - & - & - \\
5 & Cardiac glycosides & - & - & - \\
6 & Saponins & - & - & + \\
7 & Steroids & + & - & + \\
8 & Phenols & - & + & + \\
9 & Tannins & - & + & + \\
10 & Proteins & - & + & - \\
11 & Terpenoids & - & - & + \\
12 & Flavonoids & - & + & + \\
\hline
\end{tabular}

Note: + ve indicates presence, whereas - ve indicates abs ence. CEOS: Chloroform extract of Oncoba spinosa, EAOS: ethyl acetate extract of Oncoba Spinosa and EEOS: ethanol extract of Oncoba spinosa

Table II. In vitro $\alpha$-amylase inhibitory activity of Oncoba spinosa root extracts

\begin{tabular}{lllllll}
\hline Test & \multicolumn{5}{c}{ \% Inhibition Concentration $(\boldsymbol{\mu g} / \mathbf{m L})$} & \multirow{2}{*}{ IC } \\
\cline { 2 - 6 } Substance & $\mathbf{6 2 . 5} \boldsymbol{\mu g} / \mathbf{g} / \mathbf{m L}$ & $\mathbf{1 2 5} \boldsymbol{\mu g} / \mathbf{m L}$ & $\mathbf{2 5 0} \boldsymbol{\mu g} / \mathbf{m L}$ & $\mathbf{5 0 0} \boldsymbol{\mu g} / \mathbf{m L}$ & $\mathbf{1 0 0 0} \boldsymbol{\mu g} / \mathbf{m L}$ & \\
\hline CEOS & $3.61 \pm 0.42$ & $8.07 \pm 0.62$ & $12.81 \pm 0.46$ & $16.88 \pm 0.48$ & $26.80 \pm 0.58$ & $>1000 \mu \mathrm{g} / \mathrm{mL}$ \\
EAOS & $5.91 \pm 0.56$ & $16.36 \pm 0.36$ & $31.04 \pm 0.57$ & $47.55 \pm 0.20$ & $61.18 \pm 0.17$ & $589.32 \mu \mathrm{g} / \mathrm{mL}$ \\
EEOS & $8.64 \pm 0.66$ & $20.72 \pm 1.15$ & $41.43 \pm 0.99$ & $69.90 \pm 0.47$ & $79.94 \pm 0.65$ & $308.19 \mu \mathrm{g} / \mathrm{mL}$ \\
Acarbose & $18.54 \pm 0.31$ & $29.30 \pm 0.25$ & $48.05 \pm 0.67$ & $72.61 \pm 0.25$ & $82.73 \pm 0.65$ & $246.90 \mu \mathrm{g} / \mathrm{mL}$ \\
(Standard) & & & & & & \\
\hline
\end{tabular}

CEOS = chloroform extract of Oncoba spinosa; EAOS=ethylacetate extract of Oncoba spinosa, EEOS=ethanol extract of Oncoba Spinosa. Values are expressed as mean \pm SEM of triplicate measurement

The $\mathrm{IC}_{50}$ value of ethylacetate extract, EAOS was found to be $589.32 \mu \mathrm{g} / \mathrm{mL}$ whereas the ethanolic extract, EEOS showed at $308.19 \mu \mathrm{g} / \mathrm{mL}$. The $\mathrm{IC}_{50}$ of acarbose was found to be $246.90 \mu \mathrm{g} / \mathrm{mL}$ (Table II).

\section{In vitro a-glucosidase inhibition assay}

The $\alpha$-glucosidase inhibitory effect of CEOS was found to be ranging from $2.98 \pm 0.26 \%$ to $29.29 \pm 0.44 \%$. The $\alpha$ glucosidase inhibitory effect of EAOS was found to be ranging from $6.43+0.01 \%$ to $55.21+0.28 \%$ when studied at concentrations $62.5-1000 \mu \mathrm{g} / \mathrm{mL}$. At same concentration, the inhibitory effect of EEOS was found to be ranging from $14.12+0.51 \%$ to $78.68+0.36 \%$ whereas the effect of the standard drug acarbose, ranged from $19.92+0.39$ to $82.50+0.39 \%$. The $\mathrm{IC}_{50}$ value of ethylacetate extract, EAOS was found to be $914.98 \mu \mathrm{g} / \mathrm{mL}$ whereas the etha nolic extract, EEOS showed at $300.39 \mu \mathrm{g} / \mathrm{mL}$. The $\mathrm{IC}_{50}$ of acarbose was found to be $251.89 \mu \mathrm{g} / \mathrm{mL}$ (Table III).

\section{Castor oil-induced diarrhea}

In castor-oil induced diarrhea, EEOS was found to be effective in a dose dependent manner against castor oil induced diarrhea. The effect of EEOS at the dose levels of 100, 200 and $400 \mathrm{mg} / \mathrm{kg}$ caused a dose dependent decrease in the number of faecal matter from 25.33, 18.16 and 8.16 respectively. However, percent reduction in total number of faecal matter ranges from 16.95 to $73.24 \%$. EEOS at $100 \mathrm{mg} / \mathrm{kg}$ showed $15.81 \%$ inhibition of diarrhea whereas doses $200 \mathrm{mg} / \mathrm{kg}$ and 400 $\mathrm{mg} / \mathrm{kg}$ showed $30.45 \%$ and $74.37 \%$ inhibition respectively. The standard drug atropine showed $80.52 \%$ inhibition of diarrhea. The results are shown in table IV. 
Table III. In vitro $\alpha$-glucosidase inhibitory activity of Oncoba spinosa root extracts

\begin{tabular}{|c|c|c|c|c|c|c|}
\hline \multirow{2}{*}{$\begin{array}{c}\text { Test } \\
\text { Substance }\end{array}$} & \multicolumn{5}{|c|}{ \%Inhibition Concentration $(\mu \mathrm{g} / \mathrm{mL})$} & \multirow{2}{*}{$\begin{array}{c}\text { IC50 } \\
(\mu \mathrm{g} / \mathrm{mL})\end{array}$} \\
\hline & $62.5 \mu \mathrm{g} / \mathrm{mL}$ & $125 \mu \mathrm{g} / \mathrm{mL}$ & $250 \mu \mathrm{g} / \mathrm{mL}$ & $500 \mu \mathrm{g} / \mathrm{mL}$ & $1000 \mu \mathrm{g} / \mathrm{mL}$ & \\
\hline CEOS & $2.98 \pm 0.26$ & $5.94 \pm 0.44$ & $13.97 \pm 0.32$ & $22.63 \pm 0.08$ & $29.29 \pm 0.44$ & $>1000 \mu \mathrm{g} / \mathrm{mL}$ \\
\hline EAOS & $6.43 \pm 0.01$ & $11.98 \pm 0.48$ & $21.79 \pm 0.23$ & $37.03 \pm 0.12$ & $55.21 \pm 0.28$ & $914.98 \mu \mathrm{g} / \mathrm{mL}$ \\
\hline EEOS & $14.12 \pm 0.51$ & $26.68 \pm 0.49$ & $41.79 \pm 0.13$ & $66.09 \pm 0.32$ & $78.68 \pm 0.36$ & $300.39 \mu \mathrm{g} / \mathrm{mL}$ \\
\hline $\begin{array}{l}\text { Acarbose } \\
\text { (Standard) }\end{array}$ & $19.92 \pm 0.39$ & $33.23 \pm 0.28$ & $46.40 \pm 0.53$ & $66.70 \pm 0.32$ & $82.50 \pm 0.39$ & $251.89 \mu \mathrm{g} / \mathrm{mL}$ \\
\hline
\end{tabular}

CEOS $=$ chlo roform extract of Oncoba spinosa; EAOS = ethylacetate extract of Oncoba spinosa, EEOS=ethanol extract of Oncoba spinosa. Values are exp ress ed as mean \pm SEM of triplicate measurement

Table IV. Effect of EEOS on castor oil induced diarrheal

\begin{tabular}{ccccc}
\hline $\begin{array}{c}\text { Treatment } \\
\text { Group }\end{array}$ & $\begin{array}{c}\text { Total number } \\
\text { of faeces }\end{array}$ & $\begin{array}{c}\text { \%inhibition } \\
\text { of faeces }\end{array}$ & $\begin{array}{c}\text { Total number of } \\
\text { diarrheal faeces }\end{array}$ & $\begin{array}{c}\text { \%inhibition } \\
\text { of diarrhea }\end{array}$ \\
\hline Vehicle plus & $30.50 \pm 2.14$ & - & $13.66 \pm 0.84$ & - \\
castor oil $1 \mathrm{~mL}$ & & 16.95 & $11.50 \pm 0.42^{*}$ & 15.81 \\
EEOS-100mg/ $\mathrm{kg}$ & $25.33 \pm 1.94$ & 40.45 & $9.50 \pm 0.61^{* *}$ & 30.45 \\
EEOS-200mg/kg & $18.16 \pm 1.30^{* *}$ & 73.24 & $3.50 \pm 0.42^{* *}$ & 74.37 \\
EEOS-400mg/ $\mathrm{kg}$ & $8.16 \pm 0.54^{* *}$ & 8.72 & $2.66 \pm 0.33^{* *}$ & 80.52 \\
Atropine-3 $\mathrm{mg} / \mathrm{kg}$ & $4.66 \pm 0.61^{* *}$ & 84.72 &
\end{tabular}

Values are expressed as mean \pm SEM ( $\mathrm{n}=6$ in each group). $* \mathrm{P}<0.05$ and $* * \mathrm{P}<0.01$ when compared to castor oil control group.

Table V: Effect of EEOS on castor oil induced enteropooling

\begin{tabular}{cccc}
\hline $\begin{array}{c}\text { Treatment } \\
\text { Group }\end{array}$ & $\begin{array}{c}\text { Weight of the } \\
\text { intestinal content }(\mathbf{g})\end{array}$ & $\begin{array}{c}\text { Volume of intestinal } \\
\text { fluid }(\mathbf{m L})\end{array}$ & \% inhibition \\
\hline Vehicle plus & $6.10 \pm 0.58$ & $2.45 \pm 0.33$ & - \\
castor oil $1 \mathrm{~mL}$ & $5.93 \pm 0.16^{\text {ns }}$ & $2.23 \pm 0.16^{\text {ns }}$ & 8.97 \\
EEOS-100mg/kg & $4.48 \pm 0.33^{*}$ & $1.63 \pm 0.20^{*}$ & 33.46 \\
EEOS-200mg $/ \mathrm{kg}$ & $2.33 \pm 0.26^{* *}$ & $1.41 \pm 0.13^{* *}$ & 42.44 \\
EEOS-400mg/kg $/ \mathrm{kg}$ & $1.50 \pm 0.10^{* *}$ & $0.71 \pm 0.13^{* *}$ & 71.02 \\
Atropine-3mg/kg $/ \mathrm{kg}$ &
\end{tabular}

Values are expressed as mean \pm SEM ( $\mathrm{n}=6$ in each group). $* \mathrm{P}<0.05$ and $* * \mathrm{P}<0.01$ when compared to castor oil control group.

\section{Castor oil-induced enteropooling}

EEOS show ed a significant reduction in castor oil-induced fluid accumulation at $200 \mathrm{mg} / \mathrm{kg}$ and $400 \mathrm{mg} / \mathrm{kg}$ with respective values of $1.63 \pm 0.20(\mathrm{p}<0.05)$ and $1.41 \pm 0.13$ $(\mathrm{p}<0.01)$. Atropine significantly reduced $(\mathrm{p}<0.01)$ the fluid accumulation with value of $0.71 \pm 0.13$ at the dose of $3 \mathrm{mg} / \mathrm{kg}$. EEOS reduced the castor oil induced intraluminal accumulation of fluid by $8.97,33.46$ and $42.44 \%$ at doses of 100,200 and $400 \mathrm{mg} / \mathrm{kg}$ respectively. Results are shown in table V.

\section{Charcoal meal test}

In charcoal meal test, the extract at $100 \mathrm{mg} / \mathrm{kg}$ dose did not show any significant reduction in the distance travelled by the charcoal meal when compared to the castor oil control group. The gastrointestinal distance travelled by the charcoal meal in the rats significantly reduced by the extract at the doses $200 \mathrm{mg} / \mathrm{kg}$ and $400 \mathrm{mg} / \mathrm{kg}(\mathrm{P}<0.01)$. In charcoal meal test, the percent inhibition of charcoal meal was found to be $8.94 \pm 1.23$ in control group, $13.26 \pm 2.51$ in $100 \mathrm{mg} / \mathrm{kg}$ dose group, 
Table VI: Effect of EEOS on charcoal meal test

\begin{tabular}{ccccc}
\hline $\begin{array}{c}\text { Treatment } \\
\text { Group }\end{array}$ & $\begin{array}{c}\text { Length of the } \\
\text { intestine } \mathbf{( c m )}\end{array}$ & $\begin{array}{c}\text { Distance travelled } \\
\text { by the charcoal meal } \\
\text { (cms) }\end{array}$ & $\begin{array}{c}\text { Distance travelled } \\
\text { by the charcoal } \\
\text { meal (\%) }\end{array}$ & \\
\hline Vehicle plus & $72.83 \pm 1.60$ & $61.00 \pm 1.71$ & $89.04 \pm 1.33$ & $8.94 \pm 1.23$ \\
castor oil 1mL & & $56.00 \pm 1.12^{\mathrm{ns}}$ & $83.72 \pm 1.11$ & $13.26 \pm 2.51 \mathrm{~ns}$ \\
EEOS-100mg/kg & $63.33 \pm 1.43$ & $35.00 \pm 1.50^{* *}$ & $51.17 \pm 2.12^{* *}$ & $47.81 \pm 2.42^{* *}$ \\
EEOS-200mg/kg & $68.66 \pm 1.10$ & $23.00 \pm 1.25^{* *}$ & $38.17 \pm 2.51^{* *}$ & $53.61 \pm 2.31^{* *}$ \\
EEOS-400mg/kg & $65.66 \pm 2.46$ & $16.00 \pm 1.32^{* *}$ & $23.12 \pm 1.52^{* *}$ & $73.16 \pm 1.52^{* *}$ \\
\hline Atropine-3mg/kg & $69.12 \pm 2.12$ & &
\end{tabular}

Values are expressed as mean \pm SEM ( $\mathrm{n}=6$ in each group). ${ }^{*} \mathrm{P}<0.01$ when compared to castor oil control group

$47.81 \pm 2.42$ in $200 \mathrm{mg} / \mathrm{kg}$ dose group $(\mathrm{p}<0.01)$, $53.61 \pm 2.31$ in $400 \mathrm{mg} / \mathrm{kg}$ dose group $(\mathrm{p}<0.01)$ and $73.16 \pm 1.52$ in standard group $(\mathrm{p}<0.01)$. Results are shown in table VI.

Hyperglycemia has been a classical risk in the development of diabetes and the complications associated with diabetes. Therefore control of blood glucose levels is critical in the early treatment of diabetes mellitus and reduction of macro- and microvascular complications. One therapeutic approach is the prevention of carbohydrate absorption after food intake, which is facilitated by inhibition of enteric enzymes including $\alpha$ glucosidase and $\alpha$-amylase present in the brush borders of intestine. In this study, the $\alpha$ amylase and $\alpha$-glucosidase inhibitory activity of the roots of Oncoba spinosa was investigated. The inhibitory effect of CEOS, EAOS, and EEOS were analysed. Alpha amylase converts starch to maltose which reduces 3,5-dinitrosalicylic acid to 3-amino-5-nitrosalicylic acid. Inhibition of $\alpha$-amylase resulted in a decreased production of maltose. This maltose will reduce the 3,5dinitrosalicylic acid in the colouring agent to 3amino-5-nitrosalicylic acid. This reaction will produce a colour change from orange to red.

Starch $+\mathrm{H}_{2} \mathrm{O}+\alpha$-amylase -->Maltose (red colour)

The intensity of red colour will be directly proportional to the amount of maltose produced. When an enzyme inhibitor is present in the reaction mixture, digestion of starch, production of maltose and intensity of red colour produced will be less (Rao et al., 2008). $\alpha$-glucosidase will catalyze the conversion of the substrate 4-nitrophenyl-D-glucopyranoside to D-glucopyranoside and $\mathrm{p}$-nitrophenol. The yellow colour of the latter product is measured spectrophotometrically at $405 \mathrm{~nm}$.

PNPG $+\alpha$-glucosidase --> $\alpha$-D-glucopyranoside + PNP (yellow colour)

The intensity of the colour produced is directly proportional to extent of digestion of PNPG and released p-nitro phenol. Thus in the presence of an inhibitor, digestion of PNPG, production of $\mathrm{p}$-nitro phenol and intensity of colour produced will be less (Subramanian et al., 2008). Acarbose, a known $\alpha$-amylase and $\alpha$ glucosidase inhibitor, currently used in antidiabetic therapy for reducing postprandial increase in blood glucose levels, reduced the intensity of the colour produced. The plant extracts (EAOS and EEOS) also produced decrease in colour intensities in both the in vitro assays suggesting that they also possess inhibitory potential against $\alpha$-amylase and $\alpha$ glucosidase enzymes. Previous reports suggest that various potential inhibitors isolated from medicinal plants belong to flavonoid and glycoside class (Lee et al., 2008; Jong et al., 2007). Based on the preliminary phytochemical analysis, we speculate that the presence of flavonoidsand glycosides might have contributed to the $\alpha$-amylase and $\alpha$-glucosidase inhibitory activity.

The ethanolic extract which showed highest $\alpha$-amylase and $\alpha$-glucosidase inhibition was selected for antidiarrheal activity. Castor oil increases volume of intestinal content by prevention of the re-absorption of water and the liberation of ricinoleic acid from castor oil 
results in irritation and inflammation of the intestinal mucosa leading to release of prostaglandins which results in stimulation of motility and secretion and the prevention of reabsorption of $\mathrm{NaCl}$ and water (Das et al., 2007). This is characterized by an increase in the secretion of water and electrolytes, an increase in intestinal transit time and an increase in wet faeces (Oben et al., 2006). Our results showed that the extract inhibited significantly castor oil induced diarrhea in rats and the effect was almost similar to standard drug. The plant extract may have brought about this activity by re-absorption of water from the intestinal lumen or by anti prostaglandin activities that contribute to patho-physiological functions in the gastrointestinal tract. The results of our present study showed the extract at the doses $200 \mathrm{mg} / \mathrm{kg}(\mathrm{p}<0.05)$ and $400 \mathrm{mg} / \mathrm{kg}(\mathrm{p}<0.01)$ significantly reduced the volume of intestinal fluid accumulation in rats. The prevention of intraluminal fluid secretion by Oncoba spinosa in this study may be due to inhibition of prostaglandin biosynthesis with resultant decrease in secretion of fluid into the lumen or may be due to promotion of absorption of water and electrolytes in the gut. In charcoal meal test, administration of EEOS in rats caused a significant reduction in the progression of charcoal meal and in the intestinal transit time. This activity is comparable to that of atropine used here as a reference drug and which is known to reduce the intestinal motility (longanga et al., 2000). The antidiarrheal effect of EEOS could thus result from a reduction of intestinal motility and an increase in the intestinal absorption of water and electrolytes. In fact, many previous studies have shown that drugs and natural products as well, can induce their antidiarrheal effect through antispasmodic activity (Rehman et al., 2009).

Preliminary phytochemical analysis of ethanolic extract showed the presence of carbohydrates, glycosides, saponins, flavonoids, phenols, tannins and proteins. Previously various medicinal plants were screened for antidiarrheal activities and the activity is due to presence of tannins, alkaloids, saponins, flavonoids, steroids, terpenes and glycosides (Longanga et al., 2000). The presence of some of these phytochemical constituents in Oncoba spinosa may be responsible for the antidiarrheal effect.

\section{CONCLUSION}

In conclusion, the results of this investigation revealed that ethanolic extract of Oncoba spinosa contains pharmacologically active substances with antidiarrheal and antidiabetic properties. These attributes may provide the rationale for the use of Oncoba spinosa in traditional medicine for the treatment of diarrhea and diabetes. Further research is needed to fractionate the ethanolic extract and isolate the molecule(s) responsible for the antidiarrheal and antidiabetic activity.

\section{REFE RE NCES}

Apostolidis E., Kwon YI., Shetty K., 2007. Inhibitory potential of herb,fruit, and fungus enriched cheese against key enzymes linked to type 2 diabetes and hypertension. Inn. Food. Sci. Emerg. Techno. 8: 46-54.

Atta AH., Mouneir SM.,2004. Antidiarrheal activity of some Egyptian medicinal plant extracts. J. Ethnopharmacol. 92: 30309.

Bernfeld P. 1955. Amylases, alpha and beta. In: Methods in Enzymology, S. P. Colowick and N. O. Kaplan, Eds., pp. 149-158, Academic Press, New York, NY, USA.

Burkill HM.,1984. The useful plants of West Tropical Africa $2^{\text {nd }}$ edn.Families E-I. Royal Botanic Garden, Kew, 2:161-162

Burkill HM.,1994. The useful plants of West Tropical Africa $2^{\text {nd }}$ edn.Families E-I. Royal Botanic Garden, Kew, 2:161-162.

Carlos CC., Saniel M., 1990. Etiology and epidemiology of diarrhea. Phillips $J$. Microbio. Infect. Dis.19, 51-53.

Das KA, Rohini RM, Hema A., 2007. Antidiarrheal activity of Rhizophora mucronata bark extracts. Int.J.Alt.Med. 7(1).

Gershell L., 2005. Type 2 diabetes market. Nat.Rev.Drug.Discov.4, 367-368.

Hiremath MB., Jali MV., 2010. Diabetes. Indian J. Sci.Technol. 3, 1106-1108.

Jong-Anurakkun N., Bhandari MR., Kawabata J.,2007. Alpha-Glucosidase inhibitors 
from Devil tree (Alstonia scholaris). Food.Chem.103, 1319-1323.

Kaskoos RA., 2013. In-vitro $\alpha$-glucosidase inhibition and antioxidant activity of methanolic extract of Centaurea calcitrapa from Iraq. AJEONP. 1(1), 122-125.

Lee SS., Lin HC., Chen CK., 2008. Acylated flavonol monorhamnosides, alphaglucosidase inhibitors from Machilus philippinensis. Phytochemistry. 69, $2347-$ 2353.

Longanga OA., Vercruysse A., Foriers A., 2000. Contribution to ethnobotanical, phytochemical and pharmacological studies of traditionally used medicinal plants in the treatment of dysentery and diarrhea in Lomela area,Democratic Republic of Congo (DRC). J.Ethnopharmacol. 71, 411-423.

Mascolo N., Izzo AA., Avtore G., Barboto., Capasso F.,1994. Nitric oxide and castor oil induced diarrhea. J. Pharmacol. Exp. Ther. 268, 291-295.

Mujumdar AM.,1998. Antidiarrheal activity of Azadirachta indica leaf extract. Indian drugs. 35 (7), 417-420.

Oben JE., Assi SE., Agbor GA., Musoro D.,2006. Effect of Eromomastax speciosa on experimental diarrhea. Afr.J.Trad. Compl \& Alt.Med.3 (1): 95-100.

Ojewole JAO., 2008. Evaluation of antidiarrheal, anti-inflammatory and antidiabetic properties of Sclerocarya birrea (A. Rich.) Hochst stem bark aqueous extract in mice and rats. Phytother. Res.18, 601-08.
Rao TN., Kumarappan C., Thilagam E., Mohanalakshmi S., Subash MC., 2008. Inhibition of carbohydrate digestive enzymes by Talinum portulacifolium (Forssk) leaf extract. J.Complement. Integr. Med.5:1-10.

Rehman NU., Mehmood MH., Alkharfy KM., Gilani AH., 2009. Studies on antidiarrheal and antispasmodic activities of Lepidium sativum crude extract in rats. Phytother. Res.26, 136-141.

Robert A., Nezamis JE., Lancaster C., Hanchar AJ., Klepper MS.,1976. Enteropooling assay, a test for diarrhea produced by prostaglandins. Prostaglandins.11 (5), 809828.

Shoba FG., Thomas M.,2001. Study of antidiarrheal activity of four medicinal plants in castor-oil induced diarrhea. J.ethnopharmacol.76, 73-76.

Subramanian R., Asmawi MZ., Sadikun A.,2008. In-vitro $\alpha$-glucosidase and $\alpha$ amylase enzyme inhibitory effects of Andrographis paniculata extract and andrographolide. Acta. Biochim. Pol. 55, 391-398.

Uddin SJ., Shilpi JA., Alam SM., Alamgir M.,Rahman MT., Sarker SD.,2005. Antidiarrheal activity of the methanol extract of the barks of Xylocarpus moluccensis in castor oil- and magnesium sulphate induced diarrhea models in mice. J.ethnopharmacol. 101, 139-143. 